\title{
Na aquarela do discurso: memória, metáfora e metonímia
}

\author{
In the watercolor of discourse: memory, metaphor and \\ methonymy
}

\author{
Marilane Mendes Cascaes da Rosa*
}

RESUMO: Este trabalho, à luz da Análise do Discurso, mobiliza as noções teóricas memória, metáfora e metonímia. Como objeto de análise, trazemos a música Aquarela, de Toquinho. Por meio dessa materialidade discursiva, notamos o ecoar da memória, num espaço complexo de repetição e regularização, mas também de deslocamentos e conflitos. É um local movente e amplamente propício para outros dizeres. Outrossim, visualizamos a perturbação da metáfora, o (des)colorir dos sentidos para que outros possam ser pintados, numa nova trajetória onde os sentidos estilhaçam-se, num ritual que sempre pode falhar. Por outro lado, notamos a tentativa da metonímia de estabilização, de reconstrução dos sentidos, de tentar tratar da perturbação. Observamos que memória, metáfora e metonímia se constituem, imbricam-se no jogo da língua.

PALAVRAS-CHAVE: memória; metáfora; metonímia.

ABSTRACT: This study mobilizes the theoretical notions of memory, metaphor, and metonymy through Discourse Analysis. For that, we analyze Toquinho's song Aquarela. Through this discursive materiality, we notice the echo of memory, in a complex space of repetition and regularization, but also of displacements and conflicts. It is a moving place and amply conducive to other sayings. In addition, we visualize the disturbance of metaphor, the (dis)coloring of the senses so that others can be painted, in a new trajectory where the senses shatter, in a ritual that can always fail. On the other hand, we observed metonymy attempts of stabilization, reconstruction of the senses, as well as dealing with the disturbance. We observe that memory, metaphor and metonymy are constituted and interwoven in the play of the language.

KEYWORDS: memory; metaphor; metonymy.

\footnotetext{
* Doutoranda do Programa de Pós-Graduação da Universidade Federal do Rio Grande do Sul UFRGS, mestre em Ciências da Linguagem pela Universidade do Sul de Santa Catarina UNISUL, cascaes2@gmail.com, ORCID oooo-0002-3242-1315.
} 
Numa folha qualquer Eu desenho um sol amarelo E com cinco ou seis retas É fácil fazer um castelo $[\ldots]$

(TOQUINHO)

\section{Primeiras cores da aquarela: introdução}

Este trabalho se inscreve no campo discursivo, mais especificamente, na Análise do Discurso proposta por Michel Pêcheux. Assim, à luz dessa teoria, trazemos para a discussão as noções teóricas da memória, da metáfora e da metonímia, as quais se constituem, aqui, das cores da nossa aquarela, e que nos ajudarão a analisar a música Aquarela, de Toquinho. Também para abordar a metáfora e a metonímia, buscamos auxílio em Lacan (1999). Embora cada noção teórica tenha suas especificidades, o que vislumbramos é o embricamento entre elas, como se cada cor-conceito se misturasse, formando uma aquarela e diluindo-se uma na outra.

Nesta perspectiva, como Toquinho, fazemos nós a escolha pela aquarela e selecionamos as primeiras cores-conceitos: memória, metáfora e metonímia. Pretendemos com elas, mas também com outras, (des)colorir os sentidos do discurso.

\section{Pintando o discurso com memória, metáfora e metonímia}

Iniciamos nosso texto colocando na aquarela do discurso três noções fundamentais para este trabalho: memória, metáfora e metonímia. A partir delas, construiremos nossas discussões acerca da parte teórica e, também, da análise empreendida em relação ao nosso objeto. 
Figura 1 - Paleta de alguns conceitos do discurso

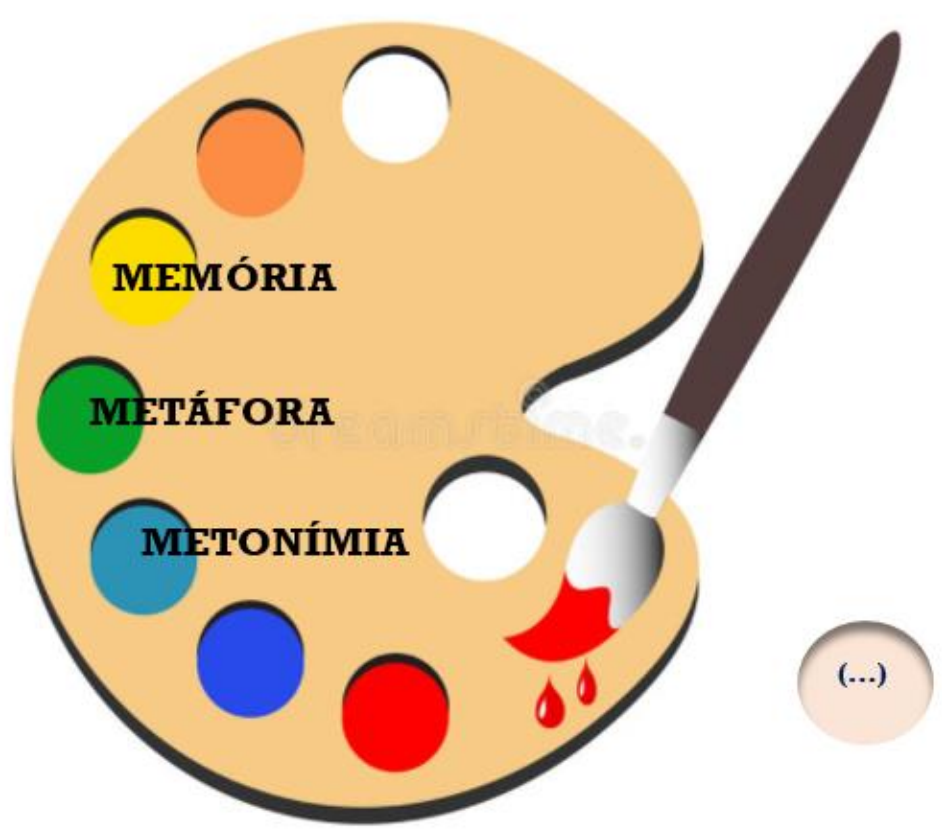

Fonte: Elaboração da autora, 2020.

A primeira delas, memória, carrega as memórias presentes, passadas e futuras; as memórias lembradas e as esquecidas; as memórias não individuais, como a memória mítica e a memória coletiva, inscritas em práticas sociais; a memória construída pelo historiador, (PÊCHEUX, 2015a, grifo do autor). Ou, segundo Indursky (1999, p. 174), a memória que promove "[...] o encontro de práticas passadas com uma prática presente". Memória que recupera do interdiscurso os sentidos, que não são fixos, mas movimentam-se, e, assim, sentidos outros podem se infiltrar, ressignificar e, também, serem esquecidos. Memória discursiva que, intradiscursivamente, jorra sobre um texto sentidos que nunca são os mesmos, pois conforme a formação discursiva a que o sujeito se filia, os sentidos se distinguem.

Para Pêcheux (2015a), a memória é uma materialidade discursiva complexa, de repetição e regularização. Logo, 
[...] seria aquilo que, face a um texto que surge como acontecimento a ler, vem reestabelecer os "implícitos" (quer dizer, mais tecnicamente, os pré-construídos, elementos citados e relatados, discursos-transversos, etc.) de que sua leitura necessita: a condição do legível em relação ao próprio legível. (PÊCHEUX, 2015a, p. 46)

Considera, ainda, que na memória haverá sempre um jogo de forças entre o repetível, a estabilização e o novo; o acontecimento discursivo que vem perturbar a memória, assim, “[...] não poderia ser concebida como uma esfera plena, cujas bordas seriam transcendais históricos e cujo conteúdo seria um sentido homogêneo, acumulado ao modo de um reservatório”. (PÊCHEUX, 2015a, p. 50). A memória é um espaço de deslocamentos, de desdobramentos, de conflitos, do já significado que ressignifica, do esquecido e silenciado que é lembrado. É espaço móvel e propício para outros dizeres.

O sujeito discursivo, determinado socio-historicamente e interpelado pela ideologia, acredita que o dizer é seu, todavia ele é fruto do já-dito, do interdiscurso. Portanto, a memória é constituída também pelo esquecimento, e isso possibilita a ruptura, a falha, o diferente, a polissemia. Pelo discurso, lembramos ou esquecemos, de acordo com a ideologia da formação discursiva onde nos inserimos.

A memória discursiva é esburacada, esgarça-se, acolhe outros discursos e traz outros sentidos. Ela

\begin{abstract}
[...] atua num movimento contínuo entre o eixo interdiscursivo e o eixo intradiscursivo, o da atualidade do dizer, ou seja, a memória não é apenas passado, é também presente e futuro, uma vez que aponta sempre a possibilidade de retorno de um já dito. É por meio deste trabalho da memória, portanto, que o sujeito dá sustentação significativa ao que diz, uma vez que é preciso filiar o dito a uma rede de sentidos anteriormente produzidos, já "memorizados", para que esse dizer "faça sentido". (FERNANDES, 2008, p. 51).
\end{abstract}

Deste modo, dizemos que a memória não é estática, ela é elástica, flexível, lacunar, mas, igualmente, saturada. Quando essa rede de repetibilidade é rompida, ocorre o que Pêcheux (2017) denominou de acontecimento discursivo, ou seja, novos sentidos são veiculados, novos arranjos se formam, os sentidos se reconfiguram, deslocam-se, é por isso que ele diz que o acontecimento ocorre "no 
ponto de encontro de uma atualidade e uma memória”. (PÊCHEUX, 2017, p. 17). Para Ferreira (2013, p. 141), “o acontecimento discursivo também se manifesta [...] como a torção de um fato da atualidade abrindo brecha para um espaço da memória." E nós queremos pensá-lo como uma "linda passarela de uma aquarela”, encontro de uma cor outra com as já existentes, uma nova cor a cobrir as passarelas do discurso e que reclamará novas discursivizações, visto que não é um simples acréscimo de uma cor a mais, já que rompe com aquela passarela de cores estabilizadas. Transpondo para o discurso, esse acontecimento exigirá um novo cenário para a língua, portanto, um novo modo de enunciar e, consequentemente, novas formas de subjetivação dos sujeitos, abrindo brechas na língua dura de madeira e exigindo que os sentidos sejam reorganizados e ressignificados. A instauração de um acontecimento discursivo faz com que os sentidos sejam transformados, e o que antes era uma utopia, por exemplo, esteja agora em "outro sítio de significância, fazendo soar novos sentidos, os quais fazem ressoar os sentidos já-postos.” (INDURSKY, 2003, p. 115).

$\mathrm{O}$ acontecimento discursivo permite a ruptura do mesmo, instaurando o novo, em torno do qual novos dizeres irão se inscrever, exigindo, então, que novos sentidos sejam interpretados, ressignificados e discursivizados. Logo, uma nova passarela. Então, para pensar essa nova passarela, adicionamos à nossa aquarela do discurso mais duas noções: metáfora e metonímia.

Inicialmente, partimos de Lacan (1999), o qual faz referências explícitas a esses dois conceitos quando teoriza o campo da cadeia significante. Assim, para ele, a metáfora seria a condensação, enquanto que a metonímia seria o deslocamento. Neste entendimento, a condensação se dá no nível da substituição, contudo, para efetuá-la, recalca-se algo. Para o autor,

É na relação de substituição que reside o recurso criador, a força criadora, a força de engendramento, caberia dizer, de metáfora. [...] é pela possibilidade de substituição que se concebe o engendramento, por assim dizer, do mundo do sentido. (LACAN, 1999, p. 35). 
Portanto, "não existe sentido senão metafórico, só surgindo o sentido da substituição de um significante por outro significante na cadeia simbólica." (LACAN, 1999, p. 16).

Igualmente, reveste-se de importância a metonímia, pois

[...] não existe objeto a não ser metonímico, sendo o objeto do desejo objeto do desejo do Outro, e sendo o desejo sempre um desejo de Outra coisa - muito precisamente, daquilo que falta, a, o objeto perdido primordialmente, na medida em que Freud mostra-o sempre pode ser reencontrado. (LACAN, 1999, p. 16).

Desta forma, a partir do que nos diz Lacan (1999), percebemos que enquanto a metáfora marca o sentido recalcado, a metonímia marca o desejo, que é o que sempre falta. Por isso, esses dois conceitos estão incessantemente em relação. No processo metafórico, o que temos é a "substituição de vários significantes por outro significante num processo de superposição”, já no processo metonímico "não há substituição de um significante por outro, mas sim um remetimento a outro significante.” (JORGE, 2005, p. 89, grifo do autor).

Em seus estudos, Lacan (1999) vai considerar crucial a metáfora e a metonímia nos processos inconscientes. Ele também inverte o algoritmo saussuriano do signo linguístico e, posteriormente, representa o significante com um $S$ maiúsculo. Segundo Lacan (1999), conforme citado por Dor (1992, p. 42), é "ele que governa no discurso do sujeito; ou mesmo que é ele que governa o próprio sujeito" e a metáfora e a metonímia são provas disso. Neste ínterim, é o significante que é supremo e não o significado. Há uma dominação do sujeito pelo significante. O sujeito é predeterminado, não controla seu discurso, embora acredite ter controle sobre ele. Segundo Dor (1992), a relação do sujeito com seu discurso constitui a noção de "fala-ser” em Lacan (1999). Conclui que:

1) O processo metafórico é o produtor de sentido, na medida em que está sustentado pela autonomia do significante em relação ao significado: eis aí a explicação dessa formulação de Lacan: "A metáfora se situa no ponto preciso onde o sentido se produz no 'non-sens"'.

2) A metáfora, no princípio de sua construção, atesta o caráter primordial do significante, no sentido de que é a cadeia dos significantes que governa a rede dos significados. 
3) O caráter primordial do significante se exerce não somente em relação ao significado, mas também em relação ao sujeito, que ele predetermina sem que este o saiba. (DOR, 1992, p. 46).

Em relação à metonímia, ou seja, ao processo em que um objeto é nomeado por meio de outro, distinto daquele que normalmente lhe é atribuído, percebemos que essa relação só é possível quando existe entre os termos uma relação de matéria a objeto, de continente a conteúdo, causa e efeito, ou, ainda, de parte pelo todo. Dessa forma, no processo metonímico, o novo significante está em relação ao anterior, diferente do que ocorre na metáfora.

Dor (1992) esquematiza o processo metafórico e o metonímico proposto por Lacan (1999):

Figura 2 - Processo metafórico

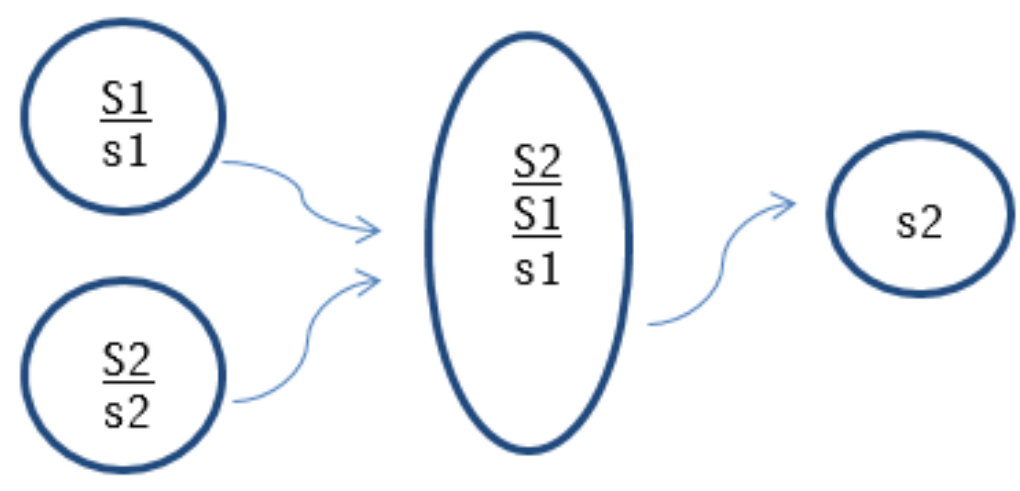

Fonte: Adaptado de Dor, 1992, p. 43.

Figura 3 - Processo metonímico

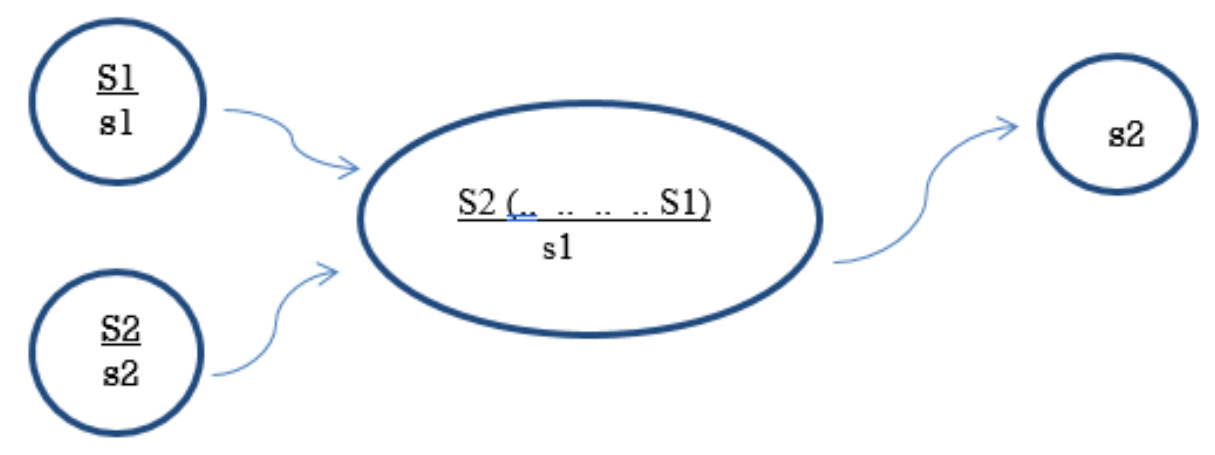

Fonte: Adaptado de Dor, 1992, p. 47. 
O que se visualiza é que enquanto na metáfora o S1 passa sob a barra da significação, fazendo com que se torne o novo significado de S2, na metonímia, o significante "descartado" não sofre esse processo, ele permanece na mesma direção, visto que o sentido está submetido à manutenção de S1 em relação à S2 e associado a s1. Na metonímia, o s2 fica expulso provisoriamente, diferente da metáfora, onde ele é afastado. No processo metonímico, os dois significantes são mantidos, impossibilitando um novo signo e, consequentemente, a associação de um significante a um significado. Na metáfora, um significante ( $\mathrm{S} 1$ ) é substituído por outro (S2), de forma que o S1 se torna o novo significado de S2, provando que é a cadeia dos significantes que comanda o conjunto dos significados e que a metáfora é uma substituição significante, conforme proposto por Lacan (1999).

A metonímia resiste à significação, de modo que a barra se mantém. Ela “apresenta-se sempre como um não-sentido aparente”; já na metáfora, o sentido é imediato, visto que há transposição da barra (DOR, 1992, p. 40). Para Lacan (1999), essas duas noções são essenciais para se compreender o inconsciente e constituem boa parte do arcabouço teórico para sustentar a tese de que $o$ inconsciente é estruturado como linguagem.

Pêcheux (2014) não fica ausente diante dos estudos de Lacan, seja em relação à metonímia ou à metáfora, embora esta ganhe uma atenção especial. Assim, a metonímia aparece quando ele fala sobre a forma-sujeito do discurso. Pêcheux (2014, p. 153) relaciona a metonímia ao discurso transverso: "o funcionamento do 'discurso- transverso' remete àquilo que, classicamente, é designado por metonímia, enquanto relação da parte com o todo, da causa com o efeito, do sintoma com o que ele designa, etc." Nesse mesmo texto, em outra ocorrência, ele diz:

É esse vínculo entre as duas representações verbais em causa que é estabelecido na discursividade, na medida em que ambas podem ser unidas à mesma formação discursiva (podendo, então, uma remeter à outra por reformulação parafrástica ou por metonímia. Esse vínculo entre as duas representações procede da identificação simbólica e, como tal, é representado através das "leis da língua" (lógica e gramática), de modo que, também aí, fica claro que todo discurso é ocultação do inconsciente. (PÊCHEUX, 2014, p. 163). 
Notamos nestas duas citações de Pêcheux (2014) uma sintonia com o que propõe Lacan (1999) sobre a metonímia, todavia, assim como na metáfora, Pêcheux vai amparar suas ideias em relação com as formações discursivas. Para Pêcheux (2014, p. 240), “o sentido existe exclusivamente nas relações de metáfora”, contudo vai conceber o sentido em relação às formações discursivas, as quais possuem fronteiras porosas. Logo, a metáfora funcionaria no deslizamento entre formações discursivas e esse efeito metafórico ocasionaria uma deriva nos sentidos.

Compreendemos a metáfora não como uma simples figura de linguagem, como apontam alguns linguistas, mas, ao modo de Lacan (1999), como substituição significante, pois a metáfora revela que "os significados extraem sua coerência unicamente da rede dos significantes, o caráter desta substituição significante demonstra a autonomia do significante em relação ao significado e, por conseguinte, a supremacia do significante.” (DOR, 1992, p. 43). Entendemola, também, ao modo de Pêcheux (2015b), como uma "perturbação, que pode tomar a forma do lapso, do ato falho, do efeito poético, do Witz ou do enigma.” (PÊCHEUX, 2015b, p. 16o).

É o movimento dos sentidos em jogo: estranhamento, perturbação, produção de sentidos outros. Eles deslizam e deixam marcas e "esse deslizamento não desaparece sem deixar traços no sujeito-ego da forma-sujeito ideológica, identificada com a evidência de um sentido”. (PÊCHEUX, 2014, p. 277, grifo do autor). Assim, por mais que o sujeito-centro-sentido se empenhe para manter o “sentido evidente" o non-sens não cessa, retorna, pressiona e é aí, nesse espaço discursivo em que o sentido se produz no non-sens, que se dá a constituição da metáfora.

As palavras, um enunciado, uma imagem, não têm um sentido próprio, literal, fixo, todavia se constituem nas relações de metáfora e recebem seus sentidos a partir das formações discursivas a que se filiam. Para Pêcheux (2014, p. 240, grifo do autor), “a metáfora, constitutiva do sentido, é sempre determinada pelo interdiscurso, isto é, por uma região do interdiscurso". O conceito de metáfora, assim proposto por Pêcheux (2014), evidencia este "estado 
de deriva” da língua. Segundo o autor, "uma palavra por outra’ é a definição da metáfora, mas é também o ponto em que o ritual se estilhaça no lapso" (PÊCHEUX, 2014, p. 277).

Neste entendimento, os sentidos sempre podem ser outros, não qualquer um, visto que são determinados ideologicamente, contudo podem deslizar e significar de diferentes maneiras. Metáfora e sentido imbricam-se, não se distinguem ou se somam, mas se implicam numa relação de nunca acabar. Assim, a metáfora é vista como a possibilidade inerente a todos os sentidos, porque esses estão inscritos na instabilidade dos dizeres possíveis, numa relação permanente de estabilização/desestabilização na língua.

Então, seja do ponto de vista da psicanálise, a partir dos estudos de Lacan, ou da análise do discurso pecheutiana, a metonímia e a metáfora são da ordem da língua, condição de existência dos sentidos e, assim sendo, está em discussão uma concepção de língua sujeita ao equívoco, às falhas, ao deslizamento significante; uma língua passível de jogo, de rupturas, deslocamentos, transgressões e rearranjos. Para nós, esses dois conceitos constituem a bússola dos sentidos, visto que nos guiam na direção deles, estabilizando-os ou desarranjando-os, fazendo parte do eixo sintático ou semântico, partindo do particular ou do universal. Todavia, embora a metáfora esteja atrelada à metonímia, em nossa concepção, é a metáfora que constitui o grande tesouro da análise do discurso, visto que é ela que move as engrenagens do sentido e faz com que os sentidos deslizem e passem a serem outros. Ela é, segundo Pêcheux (2015b), a "perturbadora".

Embora tentemos delimitar nosso percurso com as noções teóricas abordadas neste trabalho, ainda assim, elas se imbricam a outras e entre elas. Por isso, nossa paleta do discurso suscitará sempre novas cores-conceitos, que não podem ser pensadas isoladamente, como se cada cor-conceito cumprisse uma função, apenas. Ela precisa ser revisitada ao modo de Pêcheux (2014, 2015b). É uma paleta onde as cores se misturam, porque uma noção adentra a outra, os conceitos se articulam entre si, um está no outro como no nó borromeano. Além disso, cada um dos aros é constituído de um furo. E como "o sentido existe 
exclusivamente nas relações de metáfora” (PÊCHEUX, 2014, p. 240), nada melhor do que uma para finalizar essa primeira parte da discussão: o discurso é como uma aquarela, contudo, uma aquarela na qual as cores se misturam e cada cor-conceito não pode ser visto isoladamente.

Figura 4 - Paleta de alguns conceitos do discurso revisitada

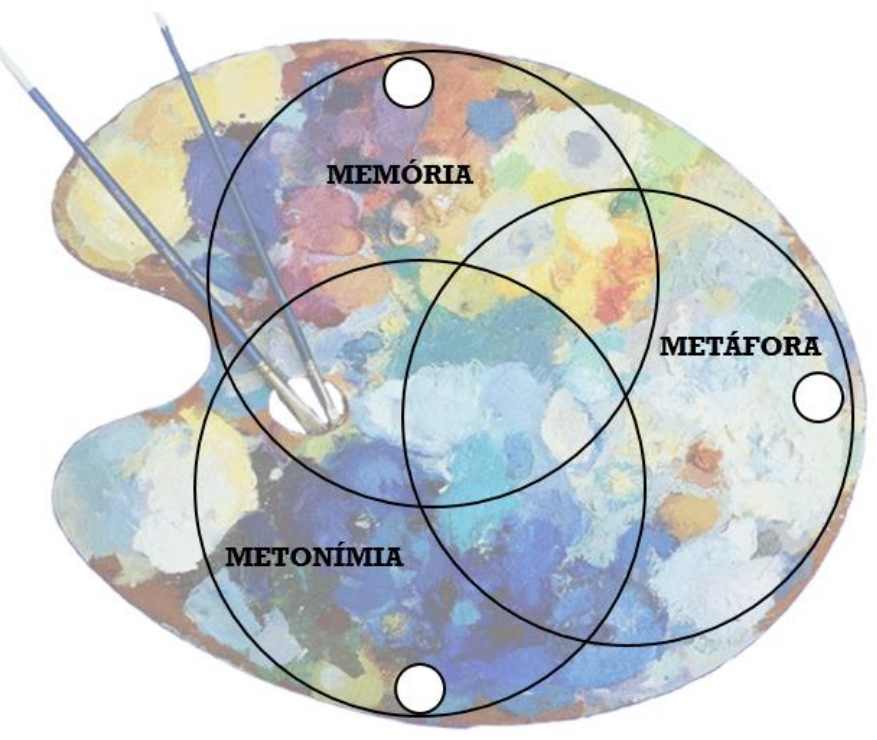

Fonte: Elaboração da autora, 2020.

Então, para a aquarela do discurso, trazemos a Aquarela de Toquinho, e misturamos as cores e as noções a fim de que outros sentidos possam ser (des)coloridos.

\section{Aquarelando a análise}

A experiência pessoal só vale se transfigurada na metáfora.

(PRADO) 
Da nossa pouca experiência, ousamos analisar a Aquarela ${ }^{110}$ discursivamente a partir dos conceitos veiculados neste texto, sobretudo os de memória, metáfora e metonímia. Assim, apresentamos seus primeiros versos:

Aquarela
Numa folha qualquer
Eu desenho um sol amarelo
É com cinco ou seis retas
É fácil fazer um castelo
Corro o lápis em torno da mão
E me dou uma luva
E se faço chover, com dois riscos
Tenho um guarda-chuva
(TOQUINHO, grifo nosso).

O título de Aquarela nos remete a efeitos de sentidos distintos: de um lado, a leveza e o quão sublime pode ser aquilo que é pintado com ela. De outro, a fragilidade de algo que não tem muita consistência, visto que é uma tinta que se dilui na água, portanto o trabalho não fica com cores fortes, demonstrando pouca resistência. Sentido, ainda, da metáfora da vida, que pouco a pouco é pintada e que, com o decorrer do tempo, começa a perder as cores. Nesse entendimento, as cores fortes de um outro tipo de tinta, de uma outra fase da vida, contrastam com a aquarela, com a velhice, com os tons desbotados. De igual modo, o desbotado do início, a leveza das cores, não é o do final do texto. No início, ainda criança, o efeito de sentido é da doçura, a delicadeza da criança, mas, em potencial, da vida em movimento. Já no final é das cores perdidas, da vida vivida, da vulnerabilidade que vem com o tempo e com ele a morte, a vida que chega ao fim e as cores da aquarela que se tornam ainda mais apagadas. O que observamos é que há, aqui, uma memória que entrelaça presente e futuro, num jogo no qual um

110 TOQUINHO. Aquarela. Disponível em: https://www.letras.mus.br/toquinho/49095/. Acesso em: 20 fev. 2020. 
mesmo significante promove efeitos de sentidos distintos e, desta forma, deslizam. E, então, um sentido por outro também é metáfora.

Percebemos, nesses versos, um sujeito desejante. Em seu imaginário está tudo aquilo que ele acha que pode fazer: um sol amarelo, um castelo, uma luva, uma linda gaivota. Um sujeito que acredita que tudo pode, todavia, como sabemos, assujeita-se à ideologia e à formação discursiva a que pertence que, nesse caso, é a da criança. Nessa formação discursiva, isso pode ser dito não porque o sujeito quer, mas porque, enquanto pertencente a ela, está autorizado a dizê-lo. Brinca com o lápis nos muitos desenhos que é capaz de traçar, assujeitase à sua condição de criança, ao pré-estabelecido.

Nesses primeiros versos, notamos a relação que o sujeito-autor faz com a aquarela, já que, por meio da memória, recuperamos do interdiscurso seus sentidos e relacionamo-la com a infância, fase que não se exige, ainda, o compromisso com um mundo lógico, que permite a fantasia, a meiguice, a sutileza. Fase da aquarela preparada para pintar, na qual tudo ganha cor e vida. A aquarela, por meio dos desenhos a serem pintados, ganha vida, e as cores se modificam, tornam-se fortes e ganham vida. Esse percurso segue por um tempo, no entanto, à medida que envelhece, a aquarela continua, mas buscando outros sentidos no interdiscurso, visto que já não se é mais criança, assim, os sentidos se modificam, percorrem outros caminhos e a aquarela volta aos tons pastel.

Nos versos seguintes, constatamos que, mesmo quando surge algo que poderia estragar o trabalho, "um pinguinho de tinta”, o sujeito dá um jeito todo especial. Há criatividade, e o desenho ganha mais vida e movimento: a gaivota, que vai levá-lo para conhecer o mundo. Aqui, percebemos a ilusão do sujeito, conforme preconiza a análise do discurso.

Se um pinguinho de tinta

Cai num pedacinho azul do papel

Num instante imagino

Uma linda gaivota a voar no céu

(TOQUINHO, grifo nosso). 
Nesse imaginário, a gaivota e a criança conseguem viajar pelo mundo, Havaí, Pequim ou Istambul, como num passe de mágica. As formações imaginárias se fazem presente e o sujeito tudo pode nesta formação discursiva. Por meio da memória, buscamos no interdiscurso os sentidos de ser criança, o mundo vivenciado por ela: pura fantasia.

\author{
Vai voando, contornando \\ A imensa curva norte-sul \\ Vou com ela viajando \\ Havaí, Pequim ou Istambul \\ Pinto um barco a vela \\ Branco navegando \\ É tanto céu e mar \\ Num beijo azul \\ Entre as nuvens vem surgindo \\ Um lindo avião rosa e grená \\ Tudo em volta colorindo \\ Com suas luzes a piscar \\ Basta imaginar e ele está partindo \\ Sereno e lindo \\ E se a gente quiser \\ Ele vai pousar \\ (TOQUINHO, grifo nosso).
}

É tudo muito dinâmico e alegre. O sujeito deixa seus desejos e sonhos virem à tona, irrompe o inconsciente e, ao fazê-lo, mostra que o sentido pode ser outro, pode escapar, diferente daqueles do mundo do adulto, que, nesse caso, ficam silenciados. Então, "o inconsciente mostra-se na fratura, na falha, no momento em que o real, ao explodir a cadeia do simbólico, desarranja o imaginário e desvanece o sujeito, que é um efeito". Ele é, portanto, "um saber que pelo equívoco se manifesta" (BARBAI, 2011, p. 379). Enquanto efeito, o sujeito vivencia esse mundo encantado e a imaginação alcança uma outra dimensão, de pura alegria.

Baldini e Mariani (2013), ao falarem sobre o funcionamento do inconsciente, mencionam que:

Um dos modos de funcionamento do inconsciente é justamente o de emergir provocando cortes no discurso efetivo, provocando falhas, esvaziando o que se diz com lapsos e chistes, mas também com 
repetições e articulações significantes que produzem furos nos sentidos e escapam aos ouvidos de quem fala. (BALDINI; MARIANI, 2013, p. 110).

Logo, o inconsciente está sempre a surpreender. E surpreende-nos dando vida, dinamicidade e colorido a simples objetos criados a partir de uma "folha qualquer" (TOQUINHO). Isso porque o sujeito do inconsciente é descontinuidade, surpreende, nunca está onde se supõe, comparece como um piscar de olhos, é efêmero, contudo comparece desfazendo os sentidos (BALDINI; MARIANI, 2013, p.110).

O que visualizamos é um sujeito atravessado pela ideologia e pelo inconsciente. De um lado, a certeza do sujeito de que controla o dizer, é dono de seus atos, tanto que "Basta imaginar [...]/ E se a gente quiser/ Ele vai pousar" (TOQUINHO), e, de outro, o inconsciente invadindo-o.

Pensar a relação entre ideologia e inconsciente não significa que um está no outro, ou que haja uma diluição deles, contudo, essa articulação, para Barbai (2011, p. 379), “indica o desequilíbrio das certezas. Ela permite se olhar para a linguagem, para aquilo que se inscreve materialmente como falha, como equívoco, como lugar do evanescente do sujeito e do sentido no mundo”. Nas palavras de Pêcheux (2014, p. 278), "a ordem do inconsciente não coincide com a da ideologia, o recalque não se identifica nem com o assujeitamento nem com a repressão, mas isso não significa que a ideologia deva ser pensada sem referência ao registro do inconsciente.” Assim, há pontos que se tocam, mas, igualmente, outros que se distanciam.

E a folha qualquer se repete e o imaginário continua fluindo, o inconsciente continua promovendo rachaduras no discurso efetivo.

\footnotetext{
Numa folha qualquer

Eu desenho um navio de partida

Com alguns bons amigos

Bebendo de bem com a vida

De uma América a outra

Consigo passar num segundo

Giro um simples compasso

E num círculo eu faço o mundo

(TOQUINHO, grifo nosso).
} 
Os versos De uma América a outra/ Consigo passar num segundo fazem com que recuperemos, por meio da memória, a história da Alice no País das Maravilhas (CARROLL, 1998), do momento em que ela adentra a toca do coelho. O sujeito, aqui, também entra na toca, mas na da ideologia, a que ele acha que quer, basta girar o compasso que tudo se transformará. Nesse mesmo giro do compasso, a vida se transforma, se descortina um novo sentido e, novamente, o inconsciente vem produzir furos, fazer fratura nos sentidos.

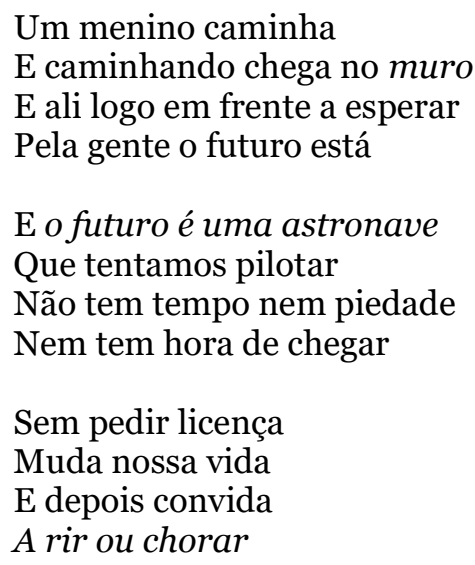

Nessa estrada não nos cabe Conhecer ou ver o que virá O fim dela ninguém sabe Bem ao certo onde vai dar (TOQUINHO, grifo nosso).

A metáfora se faz presente nos significantes muro e astronave. A partir desses versos em que esses significantes aparecem, uma nova fase será vivenciada pelo sujeito. Não é mais só brincadeira, pois o futuro vai nos convidar a também chorar, como se o choro e o sofrimento não pudessem acontecer quando se é criança. Como se todas as crianças tivessem o direito a brincar. Aqui, se silencia a infância daqueles que não a tem, de tantas crianças mundo a fora que são submetidas ao trabalho, ao sofrimento. O imaginário alcança outra dimensão: a do mundo adulto. E, igualmente, silencia a alegria que pode haver nessa fase. $\mathrm{O}$ sujeito passa a ocupar outra formação discursiva, a adulta, a qual lhe impõe outras formas de dizer e de pensar o mundo. A aquarela começa a perder as cores, a vida, tanto que ela descolorirá. 


\author{
Vamos todos \\ Numa linda passarela \\ De uma aquarela que um dia enfim \\ Descolorirá \\ Numa folha qualquer \\ Eu desenho um sol amarelo \\ Que descolorirá \\ E com cinco ou seis retas \\ É fácil fazer um castelo \\ Que descolorirá \\ Giro um simples compasso \\ E num círculo eu faço o mundo \\ Que descolorirá \\ (TOQUINHO, grifo nosso).
}

Os elementos do início do texto são retomados, contudo ganham sentidos outros, visto que tudo descolorirá. A criança se transforma em adulto e com ele vem o futuro que guarda em seu bojo a implacável ação do tempo, fazendo com que a aquarela da vida desbote, perca a cor. Aqui se silencia a beleza que pode haver na velhice, como se tudo fosse desbotado, sem vida. Como se já não houvesse mais beleza nessa fase. Outrossim, podemos recuperar o sentido da fragilidade presente nessa fase e o quão é sublime passar por ela. Os sentidos deslizam.

A Aquarela é um texto extremamente metafórico, aliás, no próprio título já vislumbramos uma metáfora, metáfora da existência, da vida, que vai sendo pintada por uma aquarela e que, no decorrer do tempo, vai perdendo a cor, vai sendo descolorida. Assim, metaforicamente, os primeiros anos de vida representam a fase da infância, posteriormente, a fase adulta e, por último, a velhice.

O poema possui várias metáforas que se constituem como partes, metonímias da metáfora maior, aquarela, a vida. Importante dizer que, "na metáfora, onde há condensação, substituição, relação de similaridade, produz-se um sentido outro para o significante” (MARIANI, 2007, p. 222). Já, na metonímia, "onde se dá deslocamento, transposição, combinação, há um novo significante para um mesmo sentido" (MARIANI, 2007, p. 222). Assim, trazendo 
para nossa materialidade o título aquarela, por exemplo, vemo-lo como metáfora, visto que o sentido de aquarela, ou seja, tinta diluída em água ou a técnica que faz uso dessa tinta, foi substituído por um outro sentido para o significante, a vida, ou as fases da vida pela qual passa uma pessoa. De outro modo, pensando na metonímia, poderíamos dizer que muro e futuro, por exemplo, são dois significantes distintos e estão sendo utilizados para representar um mesmo sentido. Em relação de contiguidade, o muro é a parte, é o que separa o passado do presente e do futuro. O muro representa o que leva ao futuro e/ou é o futuro. Vale destacar que o muro e o futuro estabelecem uma relação metafórica, pois o significante muro vem substituído por futuro. Além disso, cada elemento (metonímia) que compõe a música é parte de um todo, a música, que, também, constitui-se como metáfora e, ainda, muitos desses elementos que a compõe, igualmente, são metáforas. Observamos no texto a não fixidez tanto das noções quanto dos sentidos. As noções, os significantes e os sentidos se entrelaçam e se movimentam no jogo da língua, logo, metonímia pode se tornar metáfora e vice-versa e, nessa lógica, os sentidos estão sempre em dispersão, prestes a ruir.

A exemplo do que fez Dor (1992, p. 43), elaboramos nossa representação em relação a utilização de uma das metáforas do texto, na qual, metaforicamente, astronave serve para designar futuro. Assim, a partir de E o futuro é uma astronave, exemplificamos.

Figura 5 - Representação metafórica

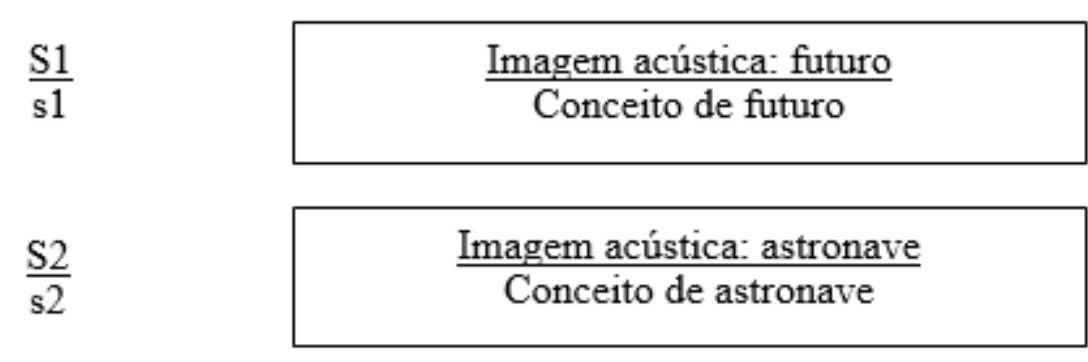

Fonte: Elaboração da autora, 2020. 
Ao introduzir a figura metafórica, fazemos uma substituição significante, que consiste em substituir S1 por S2, deste modo, como vimos na figura 2, a substituição de $\mathrm{S} 1$ por S2 faz com que $\mathrm{S} 1 / \mathrm{s} 1$ passe sob a barra da significação, o que faz com que $\mathrm{S} 2$ se torne o novo significado de S1. A significação resulta da associação de S1 a s1 que serve de significado ao término da construção metafórica. Neste caso, o significado s2 é afastado e, para reencontrá-lo, será necessária uma operação mental. A figura 6 ilustra o processo metafórico, conforme propõe Dor (1992), a partir do exemplo mencionado acima.

Figura 6 - Processo metafórico exemplificado

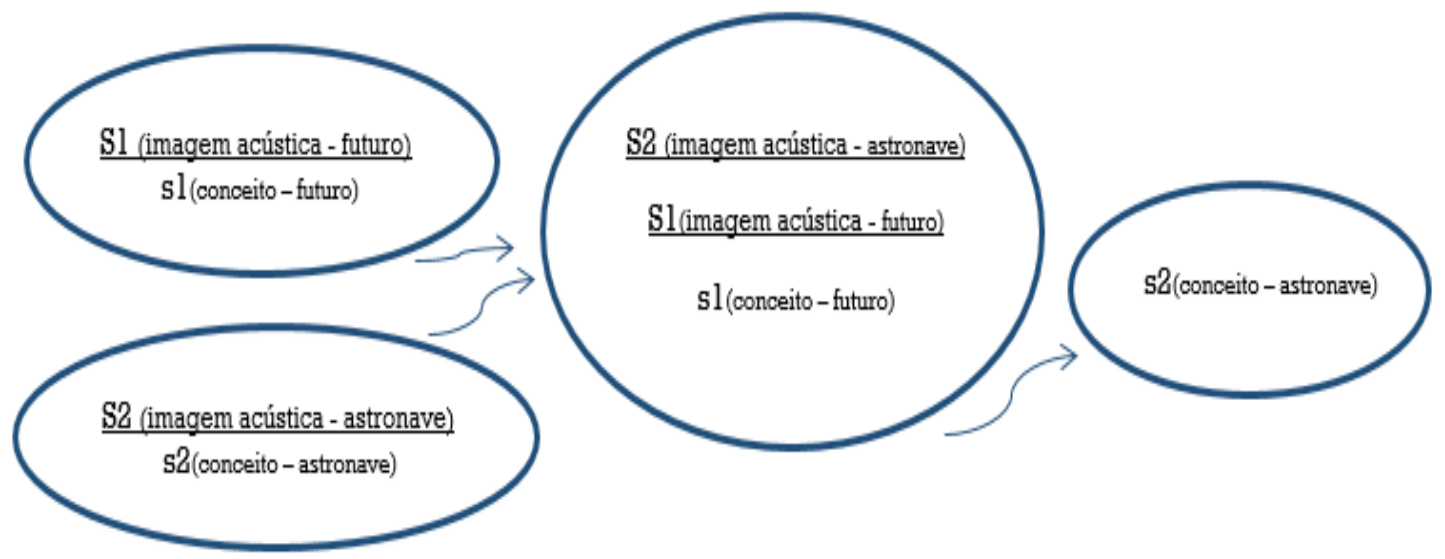

Fonte: Elaboração da autora, 2020.

De outro modo, na metonímia, como vimos, não há transposição da barra, visto que o sentido está submetido à manutenção de $\mathrm{S} 1$, em contiguidade com $\mathrm{S} 2$ e em associação a s1. O s2 é expulso temporariamente. Assim, valendo-nos da representação proposta por Dor (1992), fazemos a nossa em relação aos significantes muro e futuro que, na música, representam um mesmo sentido:

\footnotetext{
Um menino caminha

E caminhando chega no muro

E ali logo em frente a esperar

Pela gente o futuro está

(TOQUINHO, grifo nosso).
} 
Figura 7 - Representação metonímica

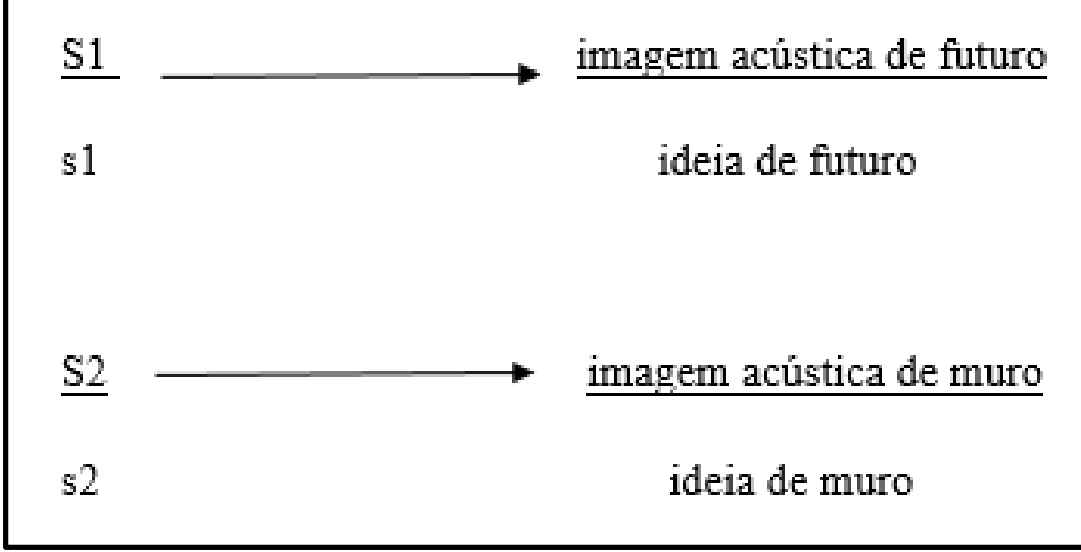

Fonte: Elaboração da autora, 2020.

Figura 8 - Processo metonímico exemplificado

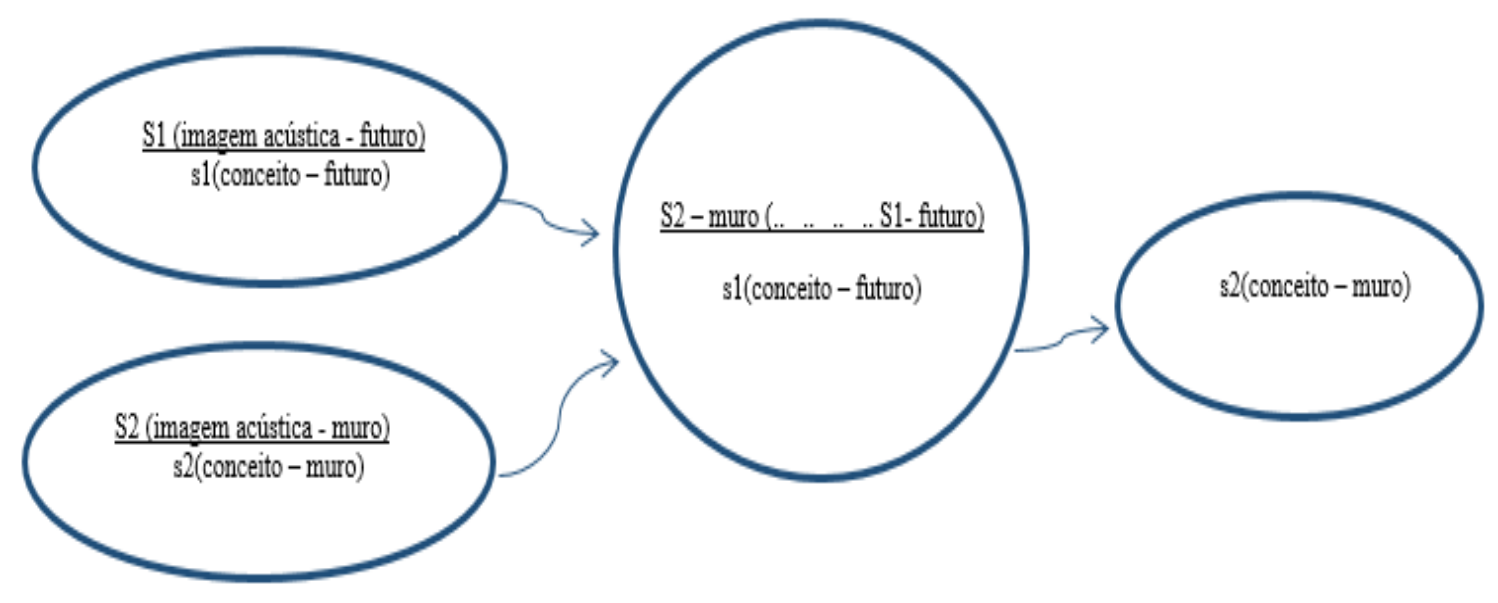

Fonte: Elaboração da autora, 2020.

A língua, para Pêcheux (2014), é dinâmica, e isso acontece porque a metáfora faz com que os sentidos se desloquem e possam ser outros. Nas palavras de Indursky (2007, p. 17), “equivale dizer que certos sentidos que são constituídos a partir de uma determinada interpelação/identificação, a partir de um certo momento, podem ser questionados e um sentido pode tornar-se um outro”. Logo, uma língua instável e heterogênea, sujeita a falhas, as quais desfazem "a regularidade do sistema naquilo que é dado como o seu centro: o nó da 
consistência /completude." (GADET; PÊCHEUX, 2004, p. 149). Uma língua afetada pelo exterior e atravessada pelo inconsciente, portanto, os sentidos sempre podem escapar uma vez que o sujeito não tem controle sobre eles.

Para Gadet e Pêcheux (2004, p. 59), "a língua domina o pensamento, impondo-lhe a ordem do negativo, do absurdo e da metáfora. É aí que a ciência da linguagem relaciona-se com o registro do inconsciente”. Logo, o sujeito não tem controle sobre ela e, assim sendo, comporta o deslizamento, a deriva dos sentidos, próprio da metáfora. Nessa perspectiva, a metáfora não é uma categoria específica dos estudos linguísticos, isto é, uma figura de linguagem; é condição de existência do discurso, pois o sentido é visto sempre em movimento, como um processo incessante, o qual se institui no interior de uma formação discursiva, sofrendo a interpelação ideológica que se coloca à língua.

No discurso, encontramos caminhos que nos levam a muitos lugares, mas a conclusão a que chegamos é a de que, à medida que os trilhamos, encontramos ainda muito mais por trilhar. A falta que a gente acha que está lá, "depois daquele moinho, que a gente pensa que vê, e das horas, que a gente não vê que não são" (ROSA, 1992), que a gente só acha, porque, na verdade, não está, sempre falta. E é justamente essa falta, esse espaço movente, que a torna dinâmica e fascinante.

Este foi nosso gesto de análise, todavia, com certeza, outros muitos podem ser realizados, pois fazemos parte de um universo não estabilizado, a falta nos habita e é justamente por faltar que, na aquarela no discurso, sempre há espaço para outras cores-conceitos e para outras combinações de cores-sentidos.

\section{Cor última: algumas considerações}

Por meio da materialidade discursiva de Aquarela ${ }^{111}$, notamos o ecoar da memória, num espaço complexo de repetição e regularização, mas também de

${ }^{111}$ TOQUINHO. Aquarela. Disponível em: https://www.letras.mus.br/toquinho/49095/. Acesso em: 20 fev. 2020. 
deslocamentos, desdobramentos e conflitos. É um local movente e amplamente propício para outros dizeres. Outrossim, visualizamos a perturbação da metáfora, o (des)colorir dos sentidos para que outros possam ser pintados, numa nova trajetória onde os sentidos estilhaçam-se num ritual que sempre pode falhar. Por outro lado, notamos a tentativa da metonímia de estabilização, de reconstrução dos sentidos, de tentar tratar da perturbação. Pelo que temos visto, memória, metáfora e metonímia se constituem, imbricam-se no jogo da língua, dos sentidos em movimento ou estabilizados. Embora estejam atreladas, em relação na linguagem, para nós, a metáfora é a bússola dos sentidos, visto que é ela que move as engrenagens dos sentidos e faz com que eles deslizem e passem a ser outros.

Vale ressaltar que, na nossa materialidade de análise, observamos, também, que um mesmo significante ora desempenhou o papel de metáfora, ora de metonímia, e isso ratifica nossa ideia inicial não só do imbrincamento entre as noções como também de que elas não ocupam uma posição fixa no discurso, mas se movimentam no jogo da língua.

E, então, como cor última dessa aquarela discursiva, deixamos a cor da mistura, daquela cor que se junta a outras e faz surgir uma nova tonalidade, da cor que se descortina para um sentido outro, da cor que suscita novas misturas, novas cores-sentido... 


\section{Referências}

BALDINI, Lauro J. S.; MARIANI, Bethania. O real é o nome que se dá ao inominável. In: INDURSKY, Freda; FERREIRA, Maria Cristina Leandro; MITTMANN, Solange (Orgs). O acontecimento do discurso no Brasil. Campinas, SP: Mercado das Letras, 2013. p. 103-114.

BARBAI, Marcos Aurélio. "E suas palavras pousam": sujeito, ideologia e inconsciente. In: RODRIGUES, E. et al. (Orgs.). Análise de Discurso no Brasil: pensando o impensado sempre. Uma homenagem a Eni Orlandi. Campinas: RG Editores, 2011. p. 373-386.

CARROLL, Lewis. Alice no país das maravilhas. Porto Alegre: L\&PM, 1998.

DOR, Joël. Introdução à leitura de Lacan: o inconsciente estruturado como linguagem. 3. ed. Porto Alegre: Artes Médicas, 1992.

FERNANDES, Carolina. O imaginário de Veja sobre "Os Lulas

Presidenciáveis”. 2008. 171f. Dissertação (Mestrado em Teorias do Texto e do Discurso) - Programa de Pós-Graduação em Letras da Universidade Federal do Rio Grande do Sul, Porto Alegre, 2008.

FERREIRA, Maria Cristina Leandro. O acontecimento discursivo como gesto de interpretação na história. In: BRESSANIN, Joelma Aparecida et al. (Orgs.). Linguagem e Interpretação: a institucionalização dos dizeres na história. Campinas: Editora RG, 2013. p. 135-145.

GADET, Françoise; PÊCHEUX, Michel. A língua inatingível: o discurso na história da lingüística. Trad. Bethania Mariani; Maria Elizabeth Chaves de Mello. Campinas: Pontes, 2004.

INDURSKY, Freda. Formação discursiva: essa noção ainda merece que lutemos por ela? In: INDURSKY, Freda; FERREIRA, Maria Cristina Leandro. Análise do discurso no Brasil: mapeando conceitos, confrontando limites. São Carlos: Claraluz, 2007. p. 163-172.

INDURSKY, Freda. Lula lá: estrutura e acontecimento. Organon, Rio Grande do Sul, v. 17, n. 35, p. 101-121, 2003.

INDURSKY, Freda. De ocupação a invasão: efeitos de sentido no discurso do/sobre o MST. In: INDURSKY, Freda; FERREIRA, Maria Cristina Leandro (Orgs). Os múltiplos territórios da Análise do Discurso. Porto Alegre: Editora Sagra Luzzatto, 1999. p. 173-188. 
JORGE, Marco Antonio Coutinho. Fundamentos da Psicanálise de Freud a Lacan: as bases conceituais. 2. ed. Rio de Janeiro: Zahar, 2005.

LACAN, Jacques. O Seminário, livro 5: as formações do inconsciente.

Tradução: Vera Ribeiro. Revisão: Marcus André Vieira. Rio de Janeiro: Jorge Zahar Ed., 1999.

MARIANI, Bethania. Silêncio e metáfora, algo para se pensar. In: INDURSKY, Freda; FERREIRA, Maria Cristina Leandro (Orgs). Análise do discurso no Brasil: mapeando conceitos, confrontando limites. São Carlos: Claraluz, 2007. p. 213-228.

PÊCHEUX, Michel. Semântica e discurso: uma crítica à afirmação do óbvio. Tradução: Eni Pulcinelli Orlandi et al. 2.ed. Campinas, SP: Editora da UNICAMP, 2014.

PÊCHEUX, Michel. Papel da memória. In: ACHARD, Pierre et al. Papel da memória. Tradução e introdução José Horta Nunes. Campinas, SP: Pontes, 2015a. p. 43-51.

PÊCHEUX, Michel. Metáfora e interdiscurso. In: Análise de Discurso: Michel Pêcheux. Textos selecionados: Eni Puccinelli Orlandi. 4. ed. Campinas, SP: Pontes Editores, 2015b.

PÊCHEUX, Michel. O discurso: estrutura ou acontecimento. Tradução: Eni P. Orlandi. 7. ed. Campinas, SP: Pontes Editores, 2017.

PRADO, Adélia. Guardião. Disponível em: https://carlofavoretto.wordpress.com/2006/04/o8/adelia-prado/. Acesso em: 20 mar. 2020.

ROSA, João Guimarães. Fita verde no cabelo: nova velha estória. Rio de Janeiro: Nova Fronteira, 1992.

TOQUINHO. Aquarela. Disponível em: https://www.letras.mus.br/toquinho/49095/. Acesso em: 20 fev. 2020.

Artigo recebido em 15 de maio de 2020 e aceito em 25 de junho de 2020. 